\title{
POWER OR PRUDENCE: WHICH IS IT?
}

\author{
Lisa A. Dolak ${ }^{\dagger}$
}

INTRODUCTION

In limiting patent litigants' access to the declaratory judgment remedy, the U.S. Court of Appeals for the Federal Circuit has primarily invoked the "actual controversy" requirement imposed by the U.S. Constitution and the federal Declaratory Judgment Act (the "Act"). However, an examination of Federal Circuit decisions and those of the district courts reveals that the courts have often confused, or blurred the distinction between, constitutional requirements and the discretion the Act affords the federal courts to decline to exercise jurisdiction. Specifically, the courts often attribute constitutional significance to factors that instead bear on policy.

The role that policy plays in patent declaratory justiciability determinations is at issue in two cases currently pending before the U.S. Supreme Court. For example, in MedImmune, Inc. v. Genentech, Inc., ${ }^{1}$ the Solicitor General has criticized the Federal Circuit for its reliance on patent policy in deciding justiciability. ${ }^{2}$ And the Petitioner in Apotex Inc. v. Pfizer Inc. ${ }^{3}$ accuses the court of "elevat[ing] that court's prudential jurisdictional doctrine (the 'reasonable apprehension' requirement) to a 'constitutional requirement." "4 But, as discussed herein, the Federal Circuit's intermingling of

\section{(C) Lisa A. Dolak 2006}

$\dagger$ Professor, Syracuse University College of Law. The preparation of this article was supported by a research and writing grant from the Syracuse University College of Law. The author acknowledges, with appreciation, the research assistance of Jenny Lim, Paula Heyman, and Cara Grisin. The author can be reached at ladolak@law.syr.edu.

${ }^{1} 427$ F.3d 958 (Fed. Cir. 2005), cert. granted, 126 S.Ct. 1329 (U.S. Feb. 21, 2006) (No. 05-608).

2 Brief for the United States as Amicus Curiae Supporting Petitioner at 23, MedImmune, 427 F.3d 958 (No. 05-608) ("Considerations of patent policy . . could not justify creation of a patent-specific test that is more rigorous than the constitutional and statutory standards that determine the existence of a justiciable case or controversy in all other contexts.").

3 Apotex Inc. v. Pfizer Inc., 159 F. App'x 1013 (Fed. Cir. 2005), petition for cert. filed, 126 S. Ct. 2057 (U.S. Feb. 9, 2006) (No. 05-1006).

${ }^{4}$ Petition for a Writ of Certiorari at 8-9, Apotex, 159 F. App'x 1013 (No. 05-1006). 
jurisdiction (i.e., the constitutional and statutory authority to hear cases) and policy is not confined to these two cases.

It is important to distinguish between jurisdictional limits and policy considerations when deciding justiciability issues in patent cases. Misapplication of the law, or even mere imprecision in the allocation of jurisdictional and prudential considerations, engenders confusion among the affected parties - litigants and potential litigants - who then bear the costs of this confusion in the form of uncertainty, higher litigation expenses, and forgone opportunities. Furthermore, when the courts are attentive to the distinction between the jurisdictional and prudential bases for justiciability decisions, they are more likely to carefully evaluate the policy implications of those determinations. Litigants, in turn, will be motivated to provide courts with more careful analysis. The likely results include the development of better policy and improved judicial decision-making.

This paper discusses the Federal Circuit's treatment of the justiciability of declaratory judgment claims in patent cases. Part I explains the jurisdictional and discretionary standards the courts apply in determining whether to adjudicate declaratory judgment claims. It further describes how the Federal Circuit has generally applied the applicable jurisdictional standards restrictively. Part II illustrates that the courts have often decided cases on jurisdictional grounds when the underlying facts have principally or exclusively prudential significance. Part III attempts to explain the courts' tendency to decide justiciability on jurisdictional as opposed to discretionary grounds. It further contends that negative jurisprudential and practical consequences flow from this tendency, among them, a continuing disregard of the policies underlying the Declaratory Judgment Act, a failure to tailor the availability of declaratory judgment relief to the particular circumstances of the cases, a lack of thoughtful analysis regarding the consequences to the litigants of justiciability decisions, and the resulting detrimental effects on the vitality of the United States patent system. Part III further contends that by focusing appropriately on prudential, or policy, considerations in justiciability determinations in patent cases, courts can reduce the incidence of inconsistent decisions, lessen confusion among litigants, encourage more thoughtful advocacy, and deliver better decisions.

\section{The Challenge For the Patent Challenger}

A patent infringement defendant typically asserts one or more declaratory judgment counterclaims in response to the patentee's claim(s) for patent infringement. Most commonly, infringement defendants request judgment on the ground that the patent at issue is invalid, ${ }^{5}$ unenforceable, ${ }^{6}$ and/or not infringed. ${ }^{7}$

${ }^{5}$ See, e.g., Biocore, AB v. Thermo Bioanalysis Corp., 79 F. Supp. 2d 422, 426 (D. Del. 1999) (noting that the infringement defendant pled invalidity and noninfringement counterclaims). Invalidity results from the failure of the patent to meet one or more statutory requirements, including, for example, the requirements that: (1) the claims 
Alternatively, a patent challenger may, in appropriate circumstances, ${ }^{8}$ institute patent litigation in federal court ${ }^{9}$ by filing a complaint requesting a declaration of patent invalidity, unenforceability, or noninfringement. ${ }^{10}$ Congress' desire to alleviate the

recite novel (35 U.S.C. §102) and nonobvious (35 U.S.C. §103) subject matter; (2) the specification enable, provide a written description for, and disclose the best mode (if there is one) of practicing the claimed invention (35 U.S.C. $§ 112$ ); and (3) the claims "particularly point out and distinctly claim" the subject invention (35 U.S.C. §112). 35 U.S.C. $\S \S 102-03,112$ (2002).

${ }^{6}$ See, e.g., Glaxo Wellcome, Inc. v. Pharmadyne Corp., 32 F. Supp. 2d 265, 268-71 (D. Md. 1998) (introducing findings of fact and conclusions of law in a patent infringement case in which the infringement defendants sought a declaratory judgment that the plaintiff's patents were invalid, unenforceable, or not infringed). A patent may be declared unenforceable based, for example, on the applicant's inequitable conduct during procurement. See, e.g., Elk Corp. v. GAF Bldg. Materials Corp., 168 F.3d 28, 32 (Fed. Cir. 1999) (affirming determination of inequitable conduct based on applicant's failure to disclose its own prior art patent and reference located in patentability search).

${ }^{7}$ See, e.g., Evans Med. Ltd. v. Am. Cyanamid Co., 980 F. Supp. 132, 138 (S.D.N.Y. 1997) (dismissing defendants' declaratory judgment counterclaims based on allegations that the asserted patents were invalid, unenforceable, and not infringed). See 35 U.S.C. $\S$ 271(a) (2003) ("whoever without authority makes, uses, offers to sell, or sells any patented invention, within the United States or imports into the United States any patented invention during the term of the patent therefor, infringes the patent").

${ }^{8}$ See infra notes $15-32$ and accompanying text.

${ }^{9}$ The federal courts have exclusive jurisdiction over cases arising under the patent laws. See 28 U.S.C. $§ 1338$ (a) (1994). According to the Federal Circuit, "[a]n action seeking declaration of patent invalidity arises under the patent law, ... as do actions seeking declaration of infringement, . . and declaration of noninfringement." Genentech, Inc. v. Eli Lilly \& Co., 998 F.2d 931, 943 (Fed. Cir. 1993) (citing EDWIN BORCHARD, DECLARATORY JUDGMENTS 808 (2d ed. 1941)).

10 "Declaratory judgment actions in the patent area are most commonly brought by potential infringers against patentees seeking a declaration of noninfringement or invalidity or both." 10A Charles A. Wright et. al. FEDERAL PRACTICE AND PROCEDURE $\S$ 2761, at 671 n.4 (2d ed. 1983) (cited in Lang v. Pac. Marine \& Supply Co., 895 F.2d 761, 763 (Fed. Cir. 1990)). See, e.g., Minds-Eye-View, Inc. v. Interactive Pictures Corp., 58 F. Supp. 2d 5, 10 (N.D.N.Y. 1999) (granting defendant-patentee's motion to dismiss alleged infringers' declaratory judgment invalidity claim); Epling v. Golden Eagle/Satellite Archery, Inc., 17 F. Supp. 2d 207, 211 (W.D.N.Y. 1998) (denying defendant-patentee's motion to dismiss or stay competitor's action seeking a declaratory judgment of noninfringement); CAE Screenplates, Inc. v. Beloit Corp., 957 F. Supp. 784, 
uncertainty faced by parties, such as alleged patent infringers, who previously lacked a cause of action, and were, therefore, unable to secure judicial determination of their rights, was a primary motivating force behind the federal Declaratory Judgment Act (the "Act"). ${ }^{11}$

790 (E.D. Va. 1997) (denying plaintiff-putative infringer's motion to compel discovery from defendant-patentee in order to establish subject matter jurisdiction over the plaintiff's claim for a declaration that the patent was invalid, unenforceable, and not infringed).

${ }^{11}$ Act of June 14, 1934, ch. 512, 48 Stat. 955. The legislative history from 1934 Congressional session is very limited because there were no debates in either the House or the Senate on the bill that year. See 78 Cong. REC. 10,564-65, 10,919 (1934) (Senate consideration); 78 CONG. REC. 8224 (1934) (House consideration). However, a bill proposing a federal declaratory judgment remedy had been introduced in every Congressional session from 1919 to 1932, and the corresponding hearings demonstrate that the primary purpose of the statute was to eliminate uncertainty. See, e.g., 1928 Hearings of H.R. 5623 Before a Subcomm. of the Senate Comm. on the Judiciary, 70th Cong., 1st Sess. 34-35 (1928) [hereinafter "1928 Senate Hearings"] (testimony of Professor Edson R. Sunderland, whose 1917 law review article (Edson R. Sunderland, $A$ Modern Evolution in Remedial Rights - The Declaratory Judgment, 16 MICH. L. REV. 69 (1917)) was instrumental in instituting the effort to pass a federal declaratory judgment statute in the United States, contending that, without the declaratory judgment remedy, parties must undergo great risks without knowledge of the respective entitlements, and concluding that the declaratory judgment "removes all that peril"); 1928 Senate Hearings, supra at 16 (letter from Judge Cardozo, then Chief Judge of the New York State Court of Appeals, describing the remedy as "a useful expedient to litigants who would otherwise have acted at their peril, or at best would have been exposed to harrowing delay."); Hearing on H.R. 10143 Before the House Comm. on the Judiciary, 67th Cong., 2d Sess. 16 (1922) [hereinafter "1922 House Hearings"] (statement of Rep. Summers) (the purpose of the declaratory judgment statute is " $[\mathrm{t}] \mathrm{o}$ remove uncertainty. It seems to me the individual citizen has as much right to be reasonably certain as to what the courts would determine his right to be as he has to be reasonably certain what the legislature has determined his rights to be.").

In his Senate testimony, Professor Sunderland described the plight of the alleged patent infringer, as follows:

I assert that I have a right to use a certain patent. You claim that you have a patent. What am I going to do about it? There is no way I can litigate my right, which I claim, to use that device, except by going ahead and using it, and you [the patent holder] can sit back as long as you please and let me run up just as high a bill of damages as you wish to have me run up, and then you may sue me for the damages, and I am ruined, having acted all the time in good 
The Act's sole requisite for jurisdiction is the presence of an "actual controversy." 12 To qualify for adjudication pursuant to the Act, a dispute must satisfy the constitutional "case or controversy" requirement. ${ }^{13}$ However, while the existence of declaratory judgment jurisdiction is an either-or proposition, many cases do not definitively fit into one category or the other. ${ }^{14}$ To assist their justiciability evaluations,

faith and on my best judgment, but having no way in the world to find out whether I had a right to use that device or not.

1928 Senate Hearings, at 35.

12 The Declaratory Judgment Act is codified at 28 U.S.C. $§ 2201$. It provides, in relevant part:

Creation of remedy

(a) In a case of actual controversy within its jurisdiction, ... any court of the United States, upon the filing of an appropriate pleading, may declare the rights and other legal relations of any interested party seeking such declaration, whether or not further relief is or could be sought. Any such declaration shall have the force and effect of a final judgment or decree and shall be reviewable as such.

Id.

${ }^{13}$ See Aetna Life Ins. Co. v. Haworth, 300 U.S. 227, 239-40 (1937) (interpreting the Act's application in an action brought by an insurance company against its insured and his beneficiary). See also Societe de Conditionnement en Aluminium v. Hunter Eng'g Co., 655 F.2d 938, 942 (9th Cir. 1981) (noting that the Act's actual controversy requirement "is the same as the 'case or controversy' requirement of Article III of the United States Constitution"); Precision Shooting Equip. Co. v. Allen, 646 F.2d 313, 314 n.4 (7th Cir. 1981) (observing that " $\mathrm{t}]$ he Declaratory Judgment Act . . . limits declaratory judgments to actual controversies in conformity with Article III, Section 2 of the Constitution").

${ }^{14}$ See BP Chem. Ltd. v. Union Carbide Corp., 4 F.3d 975, 978 (Fed. Cir. 1993) (noting that the difference between an actual controversy and a situation not ripe for adjudication "'is necessarily one of degree' . . . and is determined on the totality of the circumstances") (quoting Maryland Cas. Co. v. Pac. Coal \& Oil Co., 312 U.S. 270, 273 (1941)). See also Precision Shooting, 646 F.2d at 316 (stating that "the application of the general 'controversy' rule to a particular patent matter is not easy and may involve a determination of whether in a gray area the gray is dark enough"). 
the courts have developed more particularized standards for determining whether a declaratory judgment claim is supported by an actual controversy.

\section{A. Invoking the Patent Declaratory Judgment Jurisdiction of the District Courts}

When a party seeks to challenge a patent by way of a declaratory judgment claim, it must satisfy the district court that the Federal Circuit's two-part jurisdictional test has been met. The Federal Circuit describes the task as follows:

First, the [patentee's] conduct must have created on the part of [the] plaintiff a reasonable apprehension that the [patentee] will initiate suit if the plaintiff continues the allegedly infringing activity. Second, the plaintiff must have actually have either produced the device or have prepared to produce the device. ${ }^{15}$

Thus, the "reasonable apprehension" prong of the test focuses on the patentee's conduct; ${ }^{16}$ the "infringer activity" prong looks to the conduct of the challenger. ${ }^{17}$

${ }^{15}$ Arrowhead Indus. Water, Inc. v. Ecolochem, Inc., 846 F.2d 731, 736 (Fed. Cir. 1988).

${ }^{16} I d$. It is important to recognize that an individual patent challenger's subjective apprehension is not relevant to the actual controversy inquiry. See Phillips Plastics Corp. v. Kato Hatsujou Kabushiki Kaisha, 57 F.3d 1051, 1053 (Fed. Cir. 1995) (“The 'reasonable apprehension of suit' test requires more than the nervous state of mind of a possible infringer; it requires that the objective circumstances support such an apprehension.”).

${ }^{17}$ Reflecting the difficulties associated with articulating a workable and universally applicable standard for evaluating the "infringer activity" prong of the actual controversy test, the Federal Circuit has described this requirement variously as whether the declaratory plaintiff has engaged in "present activity which could constitute infringement or concrete steps taken with the intent to conduct such activity," (see BP Chem., 4 F.3d at 978 (citing Jervis B. Webb Co. v. Southern Sys., Inc., 742 F.2d 1388, 1398-99 (Fed. Cir. 1984))); "whether the declaratory plaintiff has acted in a way that the patentee asserts infringes the patent, or is preparing to act in such a way," (see Genentech, 998 F.2d at 936 (citing Arrowhead, 846 F.2d at 735-36)), whether the "[p]laintiff [has] engaged in an actual making, selling, or using activity subject to an infringement charge or [has] made meaningful preparation for such activity," (see Arrowhead, 846 F.2d at 736 (citing Indium Corp. v. Semi-Alloys, Inc., 781 F.2d 879, 883 (Fed. Cir. 1985))); whether the "plaintiff's conduct evidences a real interest in an activity that may, potentially, be enjoined," (Arrowhead, 846 F.2d at 738 n.10); or whether the "plaintiff . . . actually produced the accused device or . . . actually prepared to produce such a device" (see Jervis B. Webb, 742 F.2d at 1399 (citing Sweetheart Plastics, Inc. v. Illinois Tool Works, Inc. 439 F.2d 871, 875 (1st Cir. 1971))). 
Even if a court determines that an actual controversy exists, the court is not required to decide the merits of the request for declaratory relief. ${ }^{18}$ Whether to exercise jurisdiction lies in the court's discretion. At the same, time, however, the Federal Circuit has acknowledged that the discretion afforded by the Act is not unfettered. ${ }^{19}$ In the words of the court, "[t] he exercise of discretion in a declaratory judgment must have a basis in sound reason." 20

Other formulations of the test have included whether the declaratory plaintiff has "actually produced the accused article or ... engaged in preparations for production such that but for a finding that the product infringes or for extraordinary and unforeseen contingencies, the plaintiff would and could begin production immediately," (Int'l Harvester Co. v. Deere \& Co., 623 F.2d 1207, 1210 (7th Cir. 1980) (citing Sweetheart Plastics, 439 F.2d at 875)), and whether the plaintiff is "engaged in manufacturing, using or selling the invention, or . . . has the immediate intention and ability to do so," (Wembley, Inc. v. Superba Cravats, Inc., 315 F.2d 87, 89 (2d Cir. 1963) (citations omitted) (noting that "early cases required that plaintiff actually be engaged in infringing conduct, [but] this is no longer the law")).

${ }^{18}$ See Public Serv. Comm'n v. Wycoff Co., 344 U.S. 237, 241 (1952).

${ }^{19}$ See Genentech, 998 F.2d at 936 (noting that " "the court cannot refuse to entertain a declaratory judgment action on a whim"' (quoting 10A Wright et al., supra note 10, 2759, at 655-56), and that "discretion to render declaratory judgments should be exercised to effectuate the purposes of the Declaratory Judgment Act" (citing 6A JAMES W. Moore et Al., Moore's Federal Practice 157.08 [2], at 57-36 (2d ed. 1993))).

${ }^{20}$ Genentech, 998 F.2d at 936 (citing Samuel Goldwyn, Inc. v. United Artists Corp., 113 F.2d 703, 709 (3d Cir. 1940)).

Although the Supreme Court held that district courts enjoy a "unique breadth" of discretion to decline jurisdiction under the Declaratory Judgment Act, the Court expressly declined to "delineate the outer boundaries of that discretion in other cases, for example, cases raising issues of federal law or cases in which there are no parallel state proceedings." Wilton v. Seven Falls Co., 515 U.S. 277, 290 (1995). This comment is instructive with respect to declaratory judgment claims in patent cases. Most such claims are based on federal law, and coincident parallel state court proceedings will be relatively rare, given the federal courts' exclusive jurisdiction in patent cases. See 28 U.S.C. $\S$ 1338(a) (1994). Thus, it is not clear that the Supreme Court would uphold a broad exercise of discretion to decline to hear an accused infringer's action for a declaration of patent invalidity or non-infringement where a patentee has asserted infringement and the accused infringer has access to no other forum. 


\section{B. $\quad$ The Federal Circuit's "Reasonable Apprehension" Test}

When an alleged patent infringer presents its request for declaratory relief as a counterclaim to a claim for patent infringement, the courts, for obvious reasons, usually do not find it necessary to elaborate on whether the defendant had a reasonable apprehension of suit. However, when the litigation is initiated by the patent challenger, the jurisdictional inquiry most often turns on whether the plaintiff has alleged, ${ }^{21}$ and, in fact had, ${ }^{22}$ the requisite reasonable concern.

What is required to satisfy this prong of the actual controversy test in patent cases has evolved. ${ }^{23}$ Prior to the creation of the Federal Circuit, the courts generally found an actual controversy to exist whenever the patentee had accused the declaratory judgment plaintiff of infringement. ${ }^{24}$ In some cases, jurisdiction was found to lie in the absence of such a charge, and even when the patentee did not know of the plaintiff's activities relevant to the patent. ${ }^{25}$

In contrast, the Federal Circuit has held, for example, that a notice letter stating that specified products "may infringe" specified patents, offering a nonexclusive license, and requesting "some insight into [the letter recipient's] reasons" supporting any view that no license is needed, does not create an actual controversy. ${ }^{26}$ Even unequivocal assertions that products "fall[] within," "operations [are] under," or that products are

${ }^{21}$ The party invoking the jurisdiction of the district court must plead the "grounds upon which the court's jurisdiction depends." See FED. R. CIV. P. 8.

${ }^{22}$ The challenger-plaintiff is put to its proof if the patentee-defendant challenges the existence of an actual controversy. See Jervis B. Webb, 742 F.2d at 1399 (stating that "where the declaratory defendant (patentee) has denied the factual allegations that allegedly support the existence of case or controversy, the declaratory plaintiff must prove the existence of facts underlying such allegations"); see also K-Lath v. Davis Wire Corp., 15 F. Supp.2d 952, 958 (C.D. Cal. 1998) (noting that "[w]hen considering a Rule 12(b)(1) motion challenging the substance of jurisdictional allegations, the Court is not restricted to the face of the pleadings, but may review any evidence, such as declarations and testimony, to resolve any factual disputes concerning the existence of jurisdiction") (citing McCarthy v. United States, 850 F.2d 558, 560 (9th Cir. 1988)).

${ }^{23}$ See Lisa A. Dolak, Declaratory Judgment Jurisdiction in Patent Cases: Restoring the Balance Between the Patentee and the Accused Infringer, 38 B.C. L. REV. 903, 917-932 (1997).

${ }^{24}$ See id. at 917-922.

${ }^{25}$ See id.

${ }^{26}$ SRI Int'l, Inc. v. Advanced Tech. Lab., Inc., 127 F.3d 1462, 1469-70 (Fed. Cir. 1997). 
"covered by" specified patents are insufficient to create jurisdiction, in the court's view, at least if they are made during negotiations between the parties. ${ }^{27}$

This evolution is transparently reflected in the court's articulated standard. Before and since the creation of the Federal Circuit, the circuit courts of appeal generally looked for a "reasonable apprehension of liability" on the part of the declaratory judgment $_{\text {plaintiff. }}{ }^{2}$ In contrast, the Federal Circuit has required the plaintiff to demonstrate a "reasonable apprehension that it will face an infringement suit." ${ }^{29}$ Thus,

${ }^{27}$ See, e.g., Phillips Plastics Corp., 57 F.3d at 1053-54; Shell Oil Co. v. Amoco Corp., 970 F.2d 885, 888-89 (Fed. Cir. 1992).

${ }^{28}$ See, e.g., Societe de Conditionnement en Aluminium, 655 F.2d at 944 (emphasis added) ("[a]n action for a declaratory judgment that a patent is invalid, or that the plaintiff is not infringing, is a case or controversy if the plaintiff has a real and reasonable apprehension that he will be subject to liability if he continues to manufacture his product"); TRW, Inc. v. Ellipse Corp., 495 F.2d 314, 320 (7th Cir. 1974) (noting that "a reasonable apprehension of liability" is "the 'touchstone' for determining jurisdiction under the Declaratory Judgment Act."); Diamond Shamrock Corp. v. Lumbermens Mut. Cas. Co., 416 F.2d 707, 709 (7th Cir. 1969) (stating "the test for availability of declaratory judgment [is] whether there is 'reasonable apprehension of liability."'). Compare Grafon Corp. v. Hausermann, 602 F.2d 781, 784-85 (7th Cir. 1979) (reciting a "reasonable ... apprehension [of] an infringement suit or the threat of one" and holding that the district court had jurisdiction where the patentees had contacted the plaintiff's customers and potential customers and "notif[ied] them that [the plaintiff] no longer had any rights under the ... patents" or that the patentees "were seeking an injunction to prohibit [the plaintiff] from producing [the machines at issue]").

For a more recent application of the "reasonable apprehension of liability" standard outside the Federal Circuit, see Starter Corp. v. Converse, Inc., 84 F.3d 592, 595 (2d Cir. 1996) ("In a declaratory judgment action involving trademarks, the test for an "actual case or controversy" has two prongs, both of which must be satisfied in order to establish declaratory judgment jurisdiction: (1) has the defendant's conduct created a real and reasonable apprehension of liability on the part of the plaintiff, and (2) has the plaintiff engaged in a course of conduct which has brought it into adversarial conflict with the defendant.").

${ }^{29}$ Indium Corp. of Am., 781 F.2d at 883 (emphasis added) (citing Jervis B. Webb, 742 F.2d at 1398-99; see also Cygnus Therapeutic Sys. v. Alza Corp., 92 F.3d 1153, 1159 (Fed. Cir. 1996) ("an actual controversy exists if there is . . an explicit threat or other action by the patentee, which creates a reasonable apprehension on the part of the declaratory plaintiff that it will face an infringement suit . ...").

As the Solicitor General has observed in his recent amicus brief supporting the petitioner in MedImmune, Inc. v. Genentech, Inc., the Federal Circuit in one recent case raised the articulated jurisdictional bar even further. Brief for the United States as Amicus Curiae 
the Federal Circuit focuses on the plaintiff's reasonable fear of litigation, rather than a fear of ultimate liability. ${ }^{30}$ Moreover, the court in recent cases has required the plaintiff to prove that its reasonable apprehension was created by the patentee's "explicit threat" of litigation, as contrasted with an "express charge" of infringement - the standard previously applied by the court. ${ }^{31}$ The evolution is more significant when one considers that a merely a "charge of infringement," or even less, was required in pre-Federal Circuit cases. $^{32}$

Thus, the Federal Circuit's ruling in MedImmune, Inc. v. Genentech, Inc. ${ }^{33}$ was no surprise. In 1997, MedImmune and Genentech agreed that MedImmune would license several patents from Genentech, including the "Cabilly I" patent. ${ }^{34}$ The license agreement also included several pending Genentech patent applications, the claims of which were not yet finalized. ${ }^{35}$ After one of those patent applications matured into the "Cabilly II" patent, Genentech notified MedImmune that MedImmune's Synagis ${ }^{\circledR}$ product was covered by the Cabilly II patent and that MedImmune was therefore required to pay royalties on that product under the license. ${ }^{36}$ MedImmune disagreed, and while

Supporting Petitioner, supra note 2, at 15 n. 8 (citing Teva Pharm. USA, Inc. v. Pfizer, Inc., 395 F.3d 1324, 1334 (Fed. Cir. 2004) ("In order for this case to be one fit for judicial review, [the putative infringer] must be able to demonstrate that it has a reasonable apprehension of imminent suit.") (emphasis in original)).

${ }^{30}$ The difference is significant, including because the court's more restrictive interpretation of the Declaratory Judgment Act is inconsistent with the Act's purposes, and can leave the accused patent infringer in the position of accruing liability for damages, but without a forum for airing allegations of invalidity and/or noninfringement. See Dolak, supra note 23, at 932-48.

The Federal Circuit has never explained why it believes that a reasonable apprehension of suit, as opposed to liability, is required by the Act or the Constitution.

${ }^{31}$ See id. at 923-32. The Federal Circuit continues to articulate the "express charge" standard, and has disavowed the notion that it requires that the "patentee be known to be poised on the courthouse steps." See id. at 928-931. However, its decisions demonstrate that an express infringement charge may not be sufficient. See supra notes 26-27 and accompanying text.

${ }^{32}$ See supra notes 23-25 and accompanying text.

${ }^{33} 427$ F.3d 958 .

${ }^{34}$ Petition for a Writ of Certiorari at 4, MedImmune, 427 F.3d 958 (No. 05-608).

${ }^{35} \mathrm{Id}$.

${ }^{36}$ MedImmune, 427 F.3d at 962. 
continuing to pay the license royalties, filed an action requesting a declaratory judgment that the Cabilly II patent was invalid or unenforceable. ${ }^{37}$

The Federal Circuit affirmed the district court's grant of Genentech's motion to dismiss for lack of subject matter jurisdiction, stating " $[\mathrm{t}]$ he district court did not err in holding that MedImmune, since under no threat or apprehension of suit, did not have standing to bring a declaratory challenge to the Cabilly II patent." ${ }^{, 3}$ The Court relied on its prior decisions in Gen-Probe, Inc. v. Vysis, Inc. ${ }^{39}$ and MedImmune, Inc. v. Centocor, Inc. (Centocor), ${ }^{40}$ each of which involved declaratory judgment actions brought by nonbreaching licensees.

The Federal Circuit invoked its "reasonable apprehension/infringer activity" test in Gen-Probe and held that "th[e] license, unless materially breached, obliterated any reasonable apprehension of a lawsuit ...."41 Similarly, in Centocor, the court held that "[a]ny controversy that may have existed between MedImmune and Centocor prior to and during their various negotiations vanished when MedImmune executed the license agreement, which is a covenant by Centocor not to sue.",42

The Federal Circuit's disposition in the other patent declaratory judgment case currently pending before the United States Supreme Court - Apotex, Inc. v. Pfizer, Inc. ${ }^{43}$ - was equally predictable. Apotex involves a generic drug manufacturer's effort to invalidate an "Orange Book"-listed patent. ${ }^{44}$ Pfizer, the NDA holder, did not sue Apotex,

${ }^{37}$ Id.

${ }^{38}$ Id. at 965.

39359 F.3d 1376 (Fed. Cir. 2004) (holding that a district court lacks jurisdiction to entertain a declaratory judgment action brought by a licensee in good standing against its licensor).

${ }^{40} 409$ F.3d 1376 (Fed. Cir. 2005). After accepting a license from Centocor, MedImmune asserted that the licensed product did not infringed the licensed patent and that the patent was invalid and/or unenforceable, and filed a declaratory judgment action (without ceasing royalty payments) when Centocor held MedImmune to its license obligations. Id. at 1378 .

${ }^{41}$ Gen-Probe, 359 F.3d at 1381.

${ }^{42}$ Centocor, 409 F.3d at 1379.

43159 Fed.App'x 1013. The Supreme Court has requested the views of the Solicitor General. Apotex, 126 S.Ct. 2057.

${ }^{44}$ Pursuant to portions of the Drug Price Competition and Patent Term Restoration Act of 1984, Pub.L. No. 98-417, 98 Stat. 1585 (codified at 21 U.S.C. $\S \S 355,360 \mathrm{cc}$ and 35 
the ANDA applicant, before or after the expiration of the 45 day period after receiving the Apotex notice of its ANDA filing/Paragraph IV certification. ${ }^{45}$ Pfizer had sued IVAX, the first ANDA applicant for the drug at issue, and had settled that lawsuit by agreeing that IVAX would be licensed under the Pfizer patent at issue, effective as of the expiration of an earlier Pfizer patent covering the same drug product. ${ }^{46}$ Under the applicable statutory scheme, IVAX, as the first ANDA applicant, is entitled to a 180-day period of marketing exclusivity. ${ }^{47}$ Specifically, in this circumstance, the FDA is barred from approving the Apotex ANDA until the earlier of the end of IVAX's 180 market exclusivity period or a judicial declaration that the patent at issue is invalid or not infringed. ${ }^{48}$ Thus, it is in Pfizer's interest to avoid judicial scrutiny of the patent at issue pending the completion of IVAX's exclusivity period.

U.S.C. $\S \S 156,271,282$ (2003)), a brand-name drug manufacturer who has obtained Food \& Drug Administration ("FDA") marketing approval for its drug product through the FDA "New Drug Application" ("NDA") approval process must notify the FDA of all patents that "claim[] the drug for which the [NDA] applicant submitted the application . . . and with respect to which a claim of patent infringement could reasonably be asserted . . ..”2 21 U.S.C. $\S 355(b)(1),(c)(2)$. The FDA publication that identifies such patents is known as the "Orange Book." A generic drug manufacturer who wishes to utilize the FDA's “Abbreviated New Drug Application" process (and thereby obtain marketing approval for the generic drug product by virtue of its bioequivalence with the NDAapproved drug) must certify that "(I) that such [Orange Book] patent information has not been filed, (II) that such patent has expired, (III) . . . the date on which such patent will expire, or (IV) that such patent is invalid or will not be infringed by the manufacture, use, or sale of the new drug for which the application is submitted ...." 21 U.S.C. $\S 355(\mathrm{j})(2)(\mathrm{A})(\mathrm{vii})(\mathrm{I}-\mathrm{IV})$.

Under 35 U.S.C. $\S 271(\mathrm{e})(2)(\mathrm{A})$, the filing of an ANDA "for a drug claimed in a patent" constitutes an act of patent infringement if the ANDA applicant seeks approval to market the generic drug before the expiration of the patent(s) at issue (i.e., files a "Paragragh IV" certification). If the patent owner does not file suit against the ANDA applicant within 45 days after receiving the required notice of the ANDA filing, the FDA is authorized to approve the ANDA. 21 U.S.C. $\S 355(\mathrm{j})(5)(\mathrm{B})(\mathrm{iii})$. However, if/when the ANDA application commences marketing the generic drug product, the patent owner is free to sue the ANDA for infringement.

${ }^{45}$ Apotex, 385 F.Supp.2d at 190.

${ }^{46} \mathrm{Id}$.

${ }^{47}$ See 21 U.S.C. $§ 355(j)(5)(B)(i v)$.

${ }^{48}$ See id. 
Apotex filed an action against Pfizer seeking a declaration that the patent at issue was not infringed. ${ }^{49}$ The district court granted Pfizer's motion to dismiss, holding that none of (1) Pfizer's Orange Book listing, (2) Pfizer's suit against IVAX, (3) Pfizer's history of litigation against other generic drug companies (regarding other Pfizer patents and generic versions of Pfizer products), or (4) Pfizer's refusal to agree that Apotex does not infringe created the requisite reasonable apprehension of suit. ${ }^{50}$ Along the way, the district court rejected Pfizer's argument that the then-recently enacted "Medicare Amendments" to the Food, Drug and Cosmetic Act ("FDCA") 51 altered or obviated the "reasonable apprehension of suit" requirement for patent declaratory judgment actions, stating " $[\mathrm{t}]$ he Medicare Amendments do not disturb the Federal Circuit's consistent holding that the constitutional limits of an Article III court's jurisdiction in anticipatory patent infringement declaratory judgment actions are defined by the two-part reasonable apprehension test." 52 The Federal Circuit summarily affirmed, ${ }^{53}$ presumably satisfied that the Apotex facts were indistinguishable from those in Teva Pharm. USA, Inc. v. Pfizer Inc., ${ }^{54}$ which it had decided (in favor of the declaratory judgment defendant) just about a year earlier.

The court made it clear in MedImmune and Teva that the "reasonable apprehension of suit" requirement is jurisdictional. ${ }^{55}$ But policy considerations also

${ }^{49}$ Apotex, 385 F. Supp. $2 \mathrm{~d}$ at 188.

${ }^{50}$ Id. at 194.

${ }^{51}$ The Medicare Prescription Drug, Improvement, and Modernization Act of 2003, Pub.L. No. 108-173, 117 Stat. 2066 (2003) amended both the FDCA and the Patent Act to provide that if the patent owner or NDA holder does not sue the ANDA applicant within 45 days of receiving notice of the ANDA submission, the ANDA applicant may seek a declaratory judgment of non-infringement or invalidity. See 21 U.S.C. $\S$ 355(j)(5)(C) and 35 U.S.C. $\S 271(\mathrm{e})(5)$. The latter provides that in such circumstances, "the courts of the United States shall, to the extent consistent with the Constitution, have subject matter jurisdiction in any action brought by such person under section 2201 of title 28 for a declaratory judgment that such patent is invalid or not infringed." 35 U.S.C. $\S 271(\mathrm{e})(5)$.

${ }^{52}$ Apotex, 385 F. Supp. 2d at 192-93.

${ }^{53}$ Apotex, Inc. v. Pfizer, Inc., 159 Fed. App’x 1013.

54395 F.3d 1324, 1338 (Fed. Cir. 2005) ("[W]e agree with the district court that Teva failed to establish that an actual controversy existed between it and Pfizer, as required under the Declaratory Judgment Act, 28 U.S.C. $§ 2201(a) . ”)$.

${ }^{55}$ See MedImmune, 427 F.3d at 964-65 ("Thus although courts have discretion in deciding whether to accept a declaratory judgment action when the constitutional and statutory requirements are met, there is no discretion to accept an action when there is no 
played a role in these cases. The court held MedImmune controlled by Gen-Probe, where the court cited the "undesirable results" that would obtain were a non-breaching licensee permitted to sue, namely:

Allowing this action to proceed would effectively defeat [the] contractual covenants [of the license] and discourage patentees from granting licenses. In other words, in this situation, the licensor would bear all the risk, while licensee would benefit from the license's effective cap on damages or royalties in the event its challenge to the patent's scope or validity fails. ${ }^{56}$

And in his dissent from the court's denial of Teva's petition for panel rehearing and rehearing en banc, Judge Gajarsa noted that "[t]he Teva court ignores [relevant] precedent and reads general infringement policy considerations into Article III, where they do not belong." 57 As discussed below, the Federal Circuit's declaratory judgment jurisdiction is inconsistent and ambiguous with respect to the distinction between jurisdiction - the power of the lower federal courts to hear declaratory judgment cases and the appropriate role of policy considerations in declaratory judgment justiciability determinations.

\section{JUdicial POWER VS. JUdiCIAL DisCRETION}

The Federal Circuit has confused and conflated jurisdictional and prudential facts and considerations throughout its quarter-century-long tenure. The confusion is exhibited

controversy of immediacy or reality because there is no reasonable apprehension of suit."); Teva, 395 F.3d at 1333 ("In order for this case to be one fit for judicial review, Teva must be able to demonstrate that it has a reasonable apprehension of imminent suit. . .. This requirement of imminence reflects the Article III mandate that the injury in fact be 'concrete,' and 'actual or imminent, not conjectural or hypothetical.'") (citations omitted) (emphasis in original). See also Centocor, 409 F.3d at 1382 ("[T] "Te 'Hobson's choice' [of whether to litigate or take a license] about which MedImmune complains arises not from Gen-Probe, but from Article III's requirement that, before a district court exercises jurisdiction in a declaratory judgment suit, there must be an actual controversy between the parties."); Gen-Probe, 359 F.3d at 1382 ("Under these circumstances, there is not a reasonable apprehension of suit. Therefore, this court holds that no actual controversy supports jurisdiction under the Declaratory Judgment Act . ...").

${ }^{56}$ Gen-Probe, 359 F.3d at 1382.

${ }^{57}$ Teva Pharm. USA, Inc. v. Pfizer Inc., 405 F.3d 990, 994 (Fed. Cir. 2005) (Gajarsa, J. dissenting). 
both in the court's articulations of the governing standards and in its application of those standards in the appeals it hears.

\section{A. The Justiciability Standard: Constitutional Mandate or Federal Circuit Policy?}

Throughout its tenure, the court has recognized that the Act's "actual controversy" requirement is constitutionally mandated, ${ }^{58}$ and that the Act neither confers jurisdiction on the federal courts ${ }^{59}$ nor imposes jurisdictional requirements above and beyond those compelled by the Constitution. ${ }^{60}$ And, in the cases discussed herein and in many others, ${ }^{61}$ the court has used its reasonable apprehension test to determine whether

${ }^{58}$ See, e.g., MedImmune, 409 F.3d at 1382 (“[T] he 'Hobson's choice' [of whether to litigate or take a license] about which MedImmune complains arises . . . from Article III's requirement that, before a district court exercises jurisdiction in a declaratory judgment suit, there must be an actual controversy between the parties."); Fina Oil \& Chem. Co. v. Ewen, 123 F.3d 1466, 1470 (Fed. Cir. 1997) (“A declaratory judgment action permits a threatened party to resolve its potential liability, but only when the situation has progressed to an actual controversy, as required by Article III of the Constitution."); Arrowhead, 846 F.2d at 735 ("The competing considerations are of constitutional dimension: (1) there must be an actual controversy over which a federal court may exercise jurisdiction ...; (2) to proceed in the absence of a case or controversy would involve the court in rendering a forbidden advisory opinion.") (citing Aetna, 300 U.S. at 239-40 ("The Declaratory Judgment Act . . . is operative only in respect to controversies which are such in the constitutional sense.")); Goodyear Tire \& Rubber Co. v. Releasomers, Inc., 824 F.2d 953, 955 (Fed. Cir. 1987) ("It goes without saying that federal courts do not sit to render advisory opinions. Thus, the Declaratory Judgment Act requires the existence of an actual case or controversy between the parties before a federal court can constitutionally assume jurisdiction.").

${ }^{59}$ See, e.g., Foster v. Hallco Mfg. Co., Inc., 947 F.2d 469, 479 (Fed. Cir. 1991) ("Without that controversy, no suit under the Declaratory Judgment Act could be maintained because, as the Supreme Court has said, the Declaratory Judgment Act gives no independent basis for subject matter jurisdiction in district court.") (citing Skelly Oil Co. v. Phillips Petroleum Co., 339 U.S. 667, 671-72 (1950)).

${ }^{60}$ Jervis B. Webb, 742 F.2d at 1398 ("[T] he case or controversy requirement for declaratory judgment jurisdiction has been defined to be the same as the case or controversy requirement in the constitutional sense.").

${ }^{61}$ See, e.g., Capo, Inc. v. Dioptics Med. Prod., Inc., 387 F.3d 1352, 1355 (Fed. Cir. 2004) ("Declaratory justiciability of patent disputes requires both (1) a threat or other action by the patentee whereby the declaratory plaintiff has a reasonable apprehension that he will be sued for infringement, and (2) activity by the declaratory plaintiff that constitutes the alleged infringement or active preparation to conduct such activity."); Hunter Douglas, Inc. v. Harmonic Design, Inc., 153 F.3d 1318, 1326 (Fed. Cir. 1998) ("When a declaratory judgment plaintiff alleges that the claims of a patent are not infringed, 
an "actual controversy" exists, thus effectively equating its test with the constitutional minimum requirements.

Recently, however, several of the court's members have explicitly disclaimed the jurisdictional essence of the reasonable apprehension test. For example, in his opinion dissenting from the court's denial of the petition for panel rehearing and rehearing en banc in Teva Pharm. USA, Inc. v. Pfizer, Inc., Judge Gajarsa (joined by Judge Dyk) wrote: "Article III does not compel [the reasonable apprehension test], and the Supreme Court has rejected the doctrinal rigidity [the panel opinion in Teva] introduces." ${ }^{2}$ Judge Dyk (joined by Judge Gajarsa) went even further, observing that what little Supreme Court precedent exists regarding Article III and declaratory judgments "provide no support for a reasonable apprehension of imminent suit requirement," noting the Ninth Circuit's use of the " "reasonable apprehension [of] liability"” standard, and pointing out that the First Circuit has held the "reasonable apprehension" (of suit or of liability) construct "irrelevant" under particular circumstances. ${ }^{63}$

To be sure, the court has said that the reasonable apprehension test is not the only vehicle that can be used to evaluate whether an actual controversy exists. ${ }^{64}$ And on

invalid, or unenforceable, we apply a two-step test to determine whether there is an actual controversy."), overruled on other grounds by Midwest Industries, Inc. v. Karavan Trailers, Inc., 175 F.3d 1356 (Fed.Cir. 1999); Cordis Corp. v. Medtronic, Inc., 835 F.2d 859,862 (Fed. Cir. 1987) ("In declaratory judgment patent suits, there are two prerequisites for establishing the existence of a case or actual controversy between the parties: first, the defendant must have engaged in conduct giving rise to a reasonable apprehension on plaintiff's part that it will face an infringement suit or the threat of one if it commences or continues the activity in question; second, the plaintiff must have actually produced the accused device or have actually prepared to produce it.")

${ }^{62}$ Teva, 405 F.3d at 991 (Gajarsa, J., dissenting).

${ }^{63}$ Id. at 996-97 (Dyk, J., dissenting) (citing Societe de Conditionnement en Aluminium, 655 F.2d at 944 (emphasis in original)) and Sallen v. Corinthians Licenciamentos LTDA, 273 F.3d 14 (1st Cir. 2001)).

The declaratory judgment plaintiff in Sallen had lost his domain name in an arbitration proceeding and sued for a declaration that he was entitled to it under United States law. Sallen, 273 F.3d at 21-22. The First Circuit held there existed a "certain controversy" sufficient for jurisdiction. Id. at 25.

${ }^{64}$ See Fina Oil Chem. Co., 123 F.3d at 1470 ("Satisfaction of th[e] traditional two-part test is not ... a prerequisite to jurisdiction in every possible patent declaratory judgment action. Indeed, the two elements merely assure that the declaratory plaintiff has enough interest in the subject matter of the suit and that the disagreement between the parties is real and immediate enough to fulfill the 'actual controversy' requirement."). 
several occasions, it has justified the test's application with reference to its asserted practical utility. ${ }^{65}$ But the fact is that the reasonable apprehension test is the pivot on which the jurisdiction/no jurisdiction inquiry turns in most cases. Therefore, regardless of the court's characterizations of the test as "pragmatic" and "useful,"66 the reality especially for the declaratory judgment plaintiffs the court has turned away for lack of a "reasonable apprehension of suit" - is that the reasonable apprehension standard has effectively been elevated to constitutional status. Otherwise, either the court has erroneously interpreted the Act as including a jurisdictional requirement or requirements above and beyond what the Constitution requires, ${ }^{67}$ or it has imposed its own heightened

${ }^{65}$ See, e.g., Gen-Probe, 359 F.3d at 1379 ("Through its cases, this court has developed a pragmatic inquiry that focuses on not only the conduct of the patentee but also the conduct of the putative infringer: 'There must be both (1) an explicit threat or other action by the patentee, which creates a reasonable apprehension on the part of the declaratory judgment plaintiff that it will face an infringement suit, and (2) present activity which could constitute infringement or concrete steps taken with the intent to conduct such activity."') (quoting BP Chem., 4 F.3d at 978; Arrowhead, 846 F.2d at 736 (prefacing its application of the two-step test by describing it as a "[A] test often useful in evaluating complaints for declaratory judgments in patent cases").

${ }^{66}$ See id.

${ }^{67}$ In the words of the Court:

The Declaratory Judgment Act of 1934, in its limitation to 'cases of actual controversy,' manifestly has regard to the constitutional provision and is operative only in respect to controversies which are such in the constitutional sense. The word 'actual' is one of emphasis rather than of definition. Thus the operation of the Declaratory Judgment Act is procedural only. In providing remedies and defining procedure in relation to cases and controversies in the constitutional sense the Congress is acting within its delegated power over the jurisdiction of the federal courts which the Congress is authorized to establish.

Aetna, 300 U.S. at 239-40. The Court later elaborated:

Congress enlarged the range of remedies available in the federal courts but did not extend their jurisdiction. When concerned as we are with the power of the inferior federal courts to entertain litigation within the restricted area to which the Constitution and Acts of Congress confine them, 'jurisdiction' means the kinds of issues which give right of entrance to federal courts. Jurisdiction in this sense was not altered by the Declaratory Judgment Act. 
prudential standard. The former notion - that the statute itself imposes jurisdictional conditions - cannot be squared with the Supreme Court's interpretation of the Act, which interpretation the Federal Circuit has acknowledged ${ }^{68}$ As discussed below, the latter disregards Congressional intent, as reflected in the plain language of the statute. ${ }^{69}$

There is ample evidence that the court's "reasonable apprehension" standard is motivated by policy concerns. For example, the court has said that it "maintain[s] this requirement, for it 'protects quiescent patent owners against unwarranted litigation' ...."70 According to Judge Gajarsa, "[the Federal Circuit's] cases recognize reasonable apprehension, in the typical patent infringement case, as but a pragmatic attempt to give operational guidance against which patentees can structure their conduct, and control their litigation costs, in a fact-specific area of law." "71 And, in the licensee-in-goodstanding-as-plaintiff situation, the court explained:

[P]ermitting [the licensee] to pursue a lawsuit without materially breaching its license agreement yields undesirable results. [The patentee] voluntarily relinquished its statutory right to exclude by granting [the licensee] a nonexclusive license. In so doing, [the patentee] chose to avoid litigation as an avenue of enforcing its rights. Allowing this action to proceed would effectively defeat those contractual covenants and discourage patentees from granting licenses. In other words, in this situation, the licensor would bear all the risk, while licensee would benefit from the license's effective cap on damages or royalties in the event its challenge to the patent's scope or validity fails. $^{72}$

As the above examples show, on some occasions the court substantiates its reasonable apprehension test with policy justifications. On others, however, the court has

Skelly Oil, 339 U.S. at 671.

${ }^{68}$ See, e.g., Glaxo, Inc. v. Novapharm, Ltd., 110 F.3d 1562, 1570 (Fed. Cir. 1997) (citing Skelly Oil, 339 U.S. at 671-21 and Aetna, 300 U.S. at 240).

${ }^{69}$ See infra notes $81-85$ and accompanying text.

${ }^{70}$ Hunter Douglas, 153 F.3d at 1326 (quoting Arrowhead, 846 F.2d at 736).

${ }^{71}$ Teva, 405 F.3d at 991 (Gajarsa, J., dissenting) (joined by Judge Dyk).

${ }^{72}$ Gen-Probe, 359 F.3d at 1382. 
unequivocally linked its test to both the language of the Act and to the applicable constitutional constraints, as these excerpts illustrate:

From Sierra Applied Sciences, Inc. v. Advanced Energy Industries, Inc. ${ }^{73}$ :

Here, AEI's conduct created the requisite reasonable apprehension of suit as to Sierra's past sales of the $2 \mathrm{~kW}$ power supply, and such sales in fact took place within the relevant time period, establishing the district court's Article III jurisdiction to adjudicate whether the past sales of the 2 $\mathrm{kW}$ power supply constituted infringement of the ' 813 patent, and to adjudicate whether the ' 813 patent is invalid. $^{74}$

From MedImmune, Inc. v. Genentech, Inc ${ }^{75}$ :

Thus although courts have discretion in deciding whether to accept a declaratory action when the constitutional and statutory requirements are met, there is no discretion to accept an action when there is no controversy of immediacy or reality because there is not reasonable apprehension of suit. $^{76}$

And from Teva Pharmaceuticals USA, Inc. v. Pfizer, Inc. ${ }^{77}$ :

In order for this case to be one fit for judicial review, Teva must be able to demonstrate that it has a reasonable apprehension of imminent suit. Whether there is an "actual controversy" between parties having adverse legal interests depends upon whether the facts alleged show that there is a substantial controversy between the parties "of sufficient immediacy and reality to warrant the issuance of a declaratory judgment.". . . This requirement of imminence reflects the Article III mandate that the injury in fact be

\footnotetext{
73363 F.3d 1361, 1377 (Fed. Cir. 2004).

${ }^{74} I d$. at 1377 (emphasis added).

75427 F.3d 958.

${ }^{76} I d$. at $964-65$ (emphasis added).

77395 F.3d 1324.
} 
"concrete," and "actual or imminent, not conjectural or hypothetical." 78

"We do not think that the cases cited by Teva support the proposition that the reasonable apprehension of suit prong of our traditional two-part test is not a constitutional requirement."79

"We conclude that the plain language of the statute, as well as the legislative history, support the conclusion that Congress did not intend for the Medicare Amendments to cause courts to alter the requirement of the two-part test that a declaratory judgment plaintiff must demonstrate a "reasonable apprehension" of suit to establish Article III jurisdiction.", 80

In fact the court has specifically rejected a litigant's argument that the two-step test "represents a prudential rule rather than a constitutional requirement." 81 Clearly, as a matter of jurisprudential integrity, the court cannot have it both ways.

Without a doubt, the Declaratory Judgment Act accommodates the exercise of judicial discretion. The Act says "[i]n a case of actual controversy within its jurisdiction ... any court of the United States . . . may declare the rights and other legal relations of any interested party ...." 82 And the Supreme Court has flatly declared " $[t]$ his is an enabling Act, which confers a discretion on the courts rather than an absolute right upon the litigant." ${ }^{\prime 3}$ But the Act clearly distinguishes between jurisdiction and discretion, conferring upon a court the discretion to exercise - or not - the authority it possesses to decide "a case of actual controversy within its jurisdiction." It thus obliges its own twostep analysis. First, the court should determine whether the case presents an Article III controversy. Then, if (and only if) the court concludes that it has jurisdiction to decide the dispute, it should evaluate the relevant prudential considerations and decide whether the exercise of jurisdiction is appropriate.

${ }^{78}$ Id. at 1333 (citations omitted) (emphasis added).

${ }^{79} I d$. at 1335 (emphasis added).

${ }^{80} I d$. at 1337 (emphasis added).

${ }^{81}$ Id. at 1335.

8228 U.S.C. §2201 (1985) (emphasis added).

${ }^{83}$ Public Serv. Comm'n, 344 U.S. at 241. 
The Federal Circuit has, in fact, recognized the appropriate analytical framework. It has said "[t]here is no absolute right to a declaratory judgment. The Act says a court 'may' grant one. Hence, when there is a clear controversy and thus jurisdiction, a district court's decision on whether to exercise that jurisdiction is discretionary." ${ }^{84}$ The court also understands that jurisdiction is the prerequisite to the exercise of discretion, ${ }^{85}$ and that a two-step inquiry is appropriately applied. ${ }^{86}$ Thus the problem is not that the Federal Circuit has taken policy into account in evaluating declaratory judgment justiciability. The problem is the extent to which it has permitted policy to influence the first step - the constitutional or jurisdictional analysis - as evidenced by its justifications for $^{87}$ and application of its two-step reasonable apprehension/infringer activity test. ${ }^{88}$

\section{B. The Standard in Action: Which Facts are Which?}

Despite its policy justifications for its actual controversy test, the Federal Circuit has made clear that test is jurisdictional. ${ }^{89}$ Thus, the declaratory judgment plaintiff's ability to satisfy the reasonable apprehension prong (along with the infringer activity prong) is a separate inquiry from whether a court should hear or decline to hear a given declaratory claim in exercising its discretion under the Act. ${ }^{90}$ In subject matter

${ }^{84}$ Arrowhead, 846 F.2d at 735 n.6.

${ }^{85}$ See, e.g., Spectronics Corp. v. H.B. Fuller Co., 940 F.2d 631, 634 (Fed. Cir. 1991) ("When there is no actual controversy, the court has no discretion to decide the case. When there is an actual controversy and thus jurisdiction, the exercise of that jurisdiction is discretionary."), quoted in Teva, 395 F.3d at 1332 n.6, Fina Oil \& Chem. Co.,123 F.3d at 1471 n.4, and EMC Corp. v. Norand Corp., 89 F.3d 807, 810 (Fed. Cir. 1996).

${ }^{86}$ See, e.g., Capo, 387 F.3d at 1356 (agreeing with the district court that the facts presented an actual controversy, but vacating the court's decision on the given facts to decline to exercise jurisdiction as an abuse of discretion); EMC Corp., 89 F.3d at 815 (holding that although EMC had established the existence of an actual controversy, the district court did not abuse its discretion in declining to exercise jurisdiction).

${ }^{87}$ See supra notes $69-71$ and accompanying text.

${ }^{88}$ See infra notes $93-117$ and accompanying text.

${ }^{89}$ See supra notes $72-80$ and accompanying text.

${ }^{90}$ See EMC Corp., 89 F.3d at 815 (holding that the patentee's conduct was sufficient to create an actual controversy conferring jurisdiction on the district court, and upholding the district court's discretionary refusal to exercise that jurisdiction); Spectronics Corp. v. H.B. Fuller, 940 F.2d 631, 633 (Fed. Cir. 1991) (distinguishing dismissals based on the lack of an actual controversy, "and therefore jurisdiction," and those based on discretionary authority). The court in Spectronics explained the relationship between the "absolute predicate" of an actual controversy, and the discretionary authority to exercise 
jurisdiction determinations regarding declaratory judgment claims, the Federal Circuit and the district courts sometimes give separate attention to the discretionary aspects of the Act, whether ${ }^{91}$ or not ${ }^{92}$ they conclude that the jurisdictional prerequisite is met. ${ }^{93}$

the jurisdiction that controversy confers as follows: "When there is no actual controversy, the court has no discretion to decide the case. When there is an actual controversy and thus jurisdiction, the exercise of that jurisdiction is discretionary." Id. (citing Public Serv. Comm'n, 344 U.S. at 241 and Arrowhead, 846 F.2d at 735 n.6).

${ }^{91}$ See generally EMC Corp., 89 F.3d at 813-15 (evaluating the propriety of the district court's decision not to exercise discretion over alleged infringer's declaratory judgment claim against the patentee, even though the "actual controversy" requirement was met); Bristol-Myers Squibb Co. v. Rhône-Poulenc Rorer, Inc., No. 95 Civ. 8833, 1996 WL 71492, at*7 (S.D.N.Y. Feb. 20, 1996) (denying patentee's request that the court exercise discretion and refuse to hear alleged infringer's declaratory judgment action, where an actual controversy existed at the time the alleged infringer filed its complaint and no grounds for an exception to the first-filed rule were shown); KPR, Inc. v. C \& F Packing Co., Inc., No. 4:93-CV-243-Y, 1993 WL 726236, at*5 (N.D. Tex. Nov. 24, 1993) (dismissing alleged infringer's declaratory judgment claims in favor of patentee's laterfiled patent infringement claims).

${ }^{92}$ See generally Bausch \& Lomb Inc. v. Ciba Corp., 39 F. Supp. 2d 271, 274-75 (W.D.N.Y. 1999) (declining to exercise jurisdiction over contact lens manufacturer's declaratory judgment claim against patentee "[e]ven if ... [manufacturer] had met the actual-controversy requirement"); Waters Corp. v. Hewlett-Packard Co., 999 F. Supp. 167, 174 (D. Mass. 1998) (basing grant of patentee's motion to dismiss on both a lack of subject matter jurisdiction and the court's discretion to decline jurisdiction); Envtl. Dynamics, Inc. v. Robert Tyer and Assoc., Inc., 929 F. Supp. 1212, 1249-50 (N.D. Iowa 1996) (holding that propriety of deferring to sister court's jurisdiction over permanent injunction and right to revisit its own judgments constitutes separate basis - apart from lack of actual controversy - for dismissing declaratory judgment counterclaims).

${ }^{93}$ In some cases, an actual controversy existing between the parties at the time suit is filed is mooted by subsequent events. For example, the court may dismiss the patentee's infringement claim prior to consideration of the opponent's claim for a declaration of invalidity. See, e.g., Industrias Metalicas Marva, Inc. v. Lausell, No. 96-1697, 1997 WL 557626 , at *17 (D.P.R. Aug. 28, 1997) (granting summary judgment to alleged infringer on the patentee's infringement claim). Alternatively, the patentee may stipulate that the opponent's activities do not infringe the patent(s) at issue. See, e.g., Spectronics, 940 F.2d at 633 (discussing patentee's covenant not to sue, designated as a "Statement of Non Liability"); Dow Chem. Co. v. Exxon Chem. Patents, Inc., No. 94-572-SLR, 1996 WL 571541 , at *3 (D. Del. Sept. 20, 1996) (concluding that the patentee's "Statement of Nonliability is sufficient to protect [declaratory judgment] plaintiff against any reasonable apprehension of suit for any products it currently manufactures or has taken concrete steps to manufacture in the future" and, consequently, dismissing claim for declaration of non-infringement and invalidity). Alternatively, the patentee may promise 
However, as discussed below, the courts frequently base actual controversy determinations in part or in whole on considerations which should factor, if at all, only in their discretionary ruminations. This failure to distinguish between jurisdictional, or constitutional, considerations on the one hand, and discretionary, or policy, considerations on the other, occurs with respect to both prongs of the actual controversy test. Its potentially negative implications justify greater attention to the distinction.

\section{The "Reasonable Apprehension" Prong}

In defense of its restrictive stance on the availability of declaratory judgment relief against patentees, ${ }^{94}$ the Federal Circuit has admonished that "more is required than the existence of an adversely held patent," 95 and "that a patent exists does not alone

not to sue the opponent for infringement based on current or past activities. See, e.g., Super Sack Mfg. Corp. v. Chase Packaging Corp., 57 F.3d 1054, 1056-57, 1059-60 (Fed. Cir. 1995) (deciding patentee's motion to dismiss grounded on its promise, manifested in its attorney's statement in motion papers and briefs, not to sue its opponent for infringement of the patents at issue based on the challenger's past or current products); Newman-Green, Inc. v. AptarGroup, Inc., No. 97 C 3489, 1998 WL 178584, at *2 (N.D. Ill. Feb. 5, 1998) (granting patentee's motion to dismiss based upon its "unconditional promise not to sue" the declaratory judgment plaintiff for infringement in its pleading); Zip Dee, Inc. v. Dometic Corp., No. 93 C 3200, 1994 WL 8234, at *1 (N.D. Ill. Jan. 7, 1994) (evaluating the effect of the patentee's "stipulation . . . that it will never sue [the patent challenger] or its customers for infringement of the patent at issue in the litigation" on its jurisdiction over the challenger's declaratory judgment counterclaim).

In such situations, the courts have consistently held that such subsequent events divest the court of jurisdiction. See generally Super Sack, 57 F.3d at 1059-60 (affirming district court dismissal of declaratory judgment counterclaim, noting that the "promise not to sue is the heart of the matter", as the resulting "estoppel . . removes . . . any controversy sufficiently actual to confer jurisdiction"); Spectronics, 940 F.2d at 637 (holding that "[t]o proceed would 'involve the court in rendering a forbidden advisory opinion'“) (quoting Arrowhead, 846 F.2d at 735); Industrias Metalicas, 1997 WL 557626, at * 18 (concluding that it lacks jurisdiction over the declaratory judgment counterclaim once the infringement claim is dismissed, in the absence of any jurisdictional grounds independent of the infringement action); Zip Dee, 1994 WL 8234, at * 1 (holding that Article III and the Declaratory Judgment Act require it to decline what amounts, under the circumstances, to a request for an advisory opinion). This result is attributed to the constitutional and statutory requirement that the declaratory judgment claimant demonstrate that " jurisdiction over its declaratory judgment action existed at, and has continued since, the time the [claim] was filed." Spectronics, 940 F.2d at 635 (quoting Int'l Med. Prosthetics Research Assoc., 787 F.2d at 575.).

${ }^{94}$ See supra notes 26-32 and accompanying text.

${ }^{95}$ BP Chem., 4 F.3d at 978. 
create a right to challenge its validity in court." 96 The court's explication of the policy underlying the rule that the mere existence of an "adversely held patent" for jurisdiction is no more elucidating. According to the court, this rule "protects quiescent patent owners against unwarranted litigation." "98 But no credible commentator or litigant has contended that patents are vulnerable to declaratory judgment attack merely because they exist.

Such strawmen contribute little to the analysis. Clearly, persons with a mere academic interest in a particular patent's validity do not have standing to challenge it. ${ }^{99}$

${ }^{96}$ Int'l Med. Prosthetics Research Assoc., 787 F.2d at 575.

${ }^{97}$ See BP Chem., 4 F.3d at 978.

${ }^{98}$ Arrowhead, 846 F.2d at 736.

99 See Precision Shooting Equip., 646 F.2d at 316 (noting that "[a] court will not render advisory opinions or expound on academic or moot questions merely to satisfy the curiosity of the parties").

Likewise, it is well established that a party cannot satisfy the "infringer activity" requirement by asserting that "but for" the existence of the patent, it would engage in particular activity. See generally BP Chem., 4 F.3d at 980 (rejecting as insufficient the challenger's allegations that its licensee would use a specified process in the absence of the patentee's patent).

By way of comparison, the Supreme Court has held that citizen groups who allege, by way of affidavits and testimony, that their enjoyment of the river in question has been adversely affected by alleged violations of the federal Clean Water Act, have standing to sue to enforce the statute. Friends of the Earth, Inc. v. Laidlaw Envtl Servs. (TOC), Inc., 528 U.S. 167, 183 (2000). The jurisdictional requirements of the Declaratory Judgment Act were not at issue in Friends, but the Court's holding establishes that a specific "but for" averments can sufficient to satisfy Article III standing requirements. See id. at 18384. Inasmuch as the standing requirements of the Constitution and the Declaratory Judgment Act are the same (see supra notes 58-59 and accompanying text), the Supreme Court's decision in Friends undermines the notion that dismissal of a declaratory judgment claim based on a "but for" allegation is jurisdictionally mandated. $C f . B P$ Chem., 4 F.3d at 980 ("That a superior process is patented to another, and unavailable for use without a license, does not of itself create a justiciable controversy.").

It should be noted, in this regard, that the plaintiff in BP Chemicals never alleged that a justiciable controversy existed solely by virtue of the existence of the patent. The plaintiff and patentee were "competitors in the business of licensing technology for the manufacture of polymers of ethylene." $I d$. at 977. During license negotiations with existing and potential licensees of the challenger, the patentee had made statements 
Furthermore, in the main, of course, the cases presenting contested issues of declaratory judgment jurisdiction do not involve "quiescent" patentees. ${ }^{100}$ Nonetheless, jurisdiction has been found wanting even where patentees have engaged in substantial vexatious conduct. ${ }^{101}$ Rarely would the truly quiescent patent owner need the protection of the "actual controversy" requirement of the Constitution and the Act. Even in the absence of such a requirement, the expense and aggravation of patent litigation would deter purely academic attacks on patents.

More importantly, however, the protection of patent owners has been offered as a justification/basis for distinguishing between constitutionally cognizable "actual controvers[ies]," and disputes of hypothetical or abstract character. ${ }^{102}$ Yet protecting patent owners, a concededly laudable objective, ought to be regarded as a matter of legislative or judicial policy. It clearly is not a matter of the federal courts' constitutional power. Put another way, the "actual controversy" issue concerns the jurisdiction of the federal district courts, not patent policy.

In addition, many of the factors courts rely on to justify denials of jurisdiction on the basis that the reasonable apprehension prong is not satisfied should not be regarded as bearing on the court's power to hear the declaratory judgment claim. For example,

concerning the strength of its patent and its intent to enforce the patent. See id. at 978980. The challenger alleged that the patent was invalid and/or unenforceable. Thus, the parties' controversy extended beyond the challenger's wish that there were no such patent.

The BP Chemicals court's "superior process" comment is one example of the courts' tendency to set up a jurisdictional "strawman" when discussing the justiciability of declaratory judgment claims. See, e.g., Precision Shooting Equip., 646 F.2d at 316 ("A court will not render advisory opinions or expound on academic or moot questions merely to satisfy the curiosity of the parties."). See also Howard T. Markey (former Chief Judge of the Federal Circuit), On Simplifying Patent Trials, 116 F.R.D. 369, 377 n.15 (remarking, on the subject of declaratory judgment jurisdiction in patent cases, that "[c]ourts have no roving commission to destroy every invalid patent"). Such hyperbole, of course, does little to advance the inquiry in particular cases.

${ }^{100}$ See supra note 97 and accompanying text.

${ }^{101}$ See, e.g., SRI Int'l, 127 F.3d at 1469-70, Phillips Plastics Corp., 57 F.3d at 1053-54.

${ }^{102}$ See Hunter Douglas, 153 F.3d at 1326-27 ("We have maintained this requirement, for it 'protects quiescent patent owners against unwarranted litigation' under Title 35 . The 'reasonable apprehension' prong of the two-part test thus contributes to policing the boundary between a constitutional controversy, which is judicially cognizable under the Declaratory Judgment Act, and 'a difference or dispute of a hypothetical or abstract or character,' which is not.") (quoting Arrowhead, 846 F.2d at 736 and Aetna, 300 U.S. at 240). 
accused infringers who initiate declaratory judgment actions while license or settlement negotiations are pending can expect to have the courthouse door slammed in their faces. ${ }^{103}$ The courts generally deem the patentee's willingness to engage in negotiations, even where it has not promised to forbear initiating its own suit, as negating any reasonable apprehension of suit on the part of the potential infringer. ${ }^{104}$ The courts have similarly regarded other factors as having constitutional significance in the jurisdictional calculus, such as the fact that (1) the patentee's "cease and desist" letter was sent by the patentee's in-house executive (as opposed to outside counsel), ${ }^{105}$ (2) the potential infringer initiated the contact between the parties, ${ }^{106}$ or even (3) the patentee is not a large business concern. ${ }^{107}$

In reality, however, these factors in no way negate the existence of a real, immediate, legal controversy between the parties. As the Federal Circuit has itself acknowledged, the potential infringer's participation in license negotiations is often principally attributable to the patentee's spoken or unspoken threat of litigation. ${ }^{108}$ By

${ }^{103}$ See, e.g., Phillips, 57 F.3d at 1053-54 (regarding the "ongoing license negotiations" between the patentee and a potential infringer as a significant factor in negating the existence of an actual controversy); Shell Oil, 970 F.2d at 888 (holding that the patentee's statement that the declaratory judgment claimant's activities "fall within" the claims of the patent was not an express charge of infringement and did not give rise to a reasonable apprehension of suit because it was made in the context of license negotiations).

${ }^{104}$ See generally id.

${ }^{105}$ See, e.g., Dataline, Inc. v. MCI WorldCom Network Serv., Inc., No. 00 Civ. 1578, 2001 WL 102336, at*4 (S.D.N.Y. Feb. 6, 2001).

106 See, e.g., CAE Screenplates, Inc. v. Beloit Corp., 957 F. Supp. 784, 790 (E.D.Va. 1997) (including among its reasons for holding that there was no reasonable apprehension of suit, the fact that the contact between the declaratory judgment plaintiff and the patentee was initiated by the plaintiff).

${ }^{107}$ See, e.g., Ryobi Am. Corp. v. Peters, 815 F. Supp. 172, 175 (D.S.C. 1993) (noting that the patentee is "an individual who has created a small side line business in his home workshop).

${ }^{108}$ EMC Corp., 89 F.3d at 811 . In the words of the court:

To be sure, any time parties are in negotiations over patent rights, the possibility of a lawsuit looms in the background. No patent owner with any sense would open negotiations by assuring his opposite party that he does not intend to enforce his patent rights under any circumstances. The threat of enforcement - either directly by the patentee or indirectly by a third party to whom the patentee licenses or 
the same token, the potential infringer's willingness to engage in negotiations does not necessarily mean that it has no valid basis for challenging the patent. Both parties are presumably at the negotiation table, at least in part, to try to avoid the substantial costs associated with patent litigation. ${ }^{109}$ And relying on the fact that the patentee communicated via its in-house executive, the potential infringer contacted the patentee first, or the patentee is "small" to conclude that a federal court lacks power to adjudicate a real, concrete, substantial dispute about a patent's validity, enforceability, or infringement between a putative infringer who will otherwise suffer injury and a patentee is no less than absurd. Such factors may constitute good reason for refusing to exercise, on a discretionary basis, the jurisdiction the court possesses. But they do not change the fact that a true controversy exists between the parties, and ought not to be held to negate the "actual controversy" required by the Act and the Constitution. 110

sells the patent - is the entire source of the patentee's bargaining power. ... Thus, it is unrealistic to suggest that some negotiating patentees intend to enforce their patents while some do not, and that the first group is subject to declaratory judgment jurisdiction while the second is not.

Id.

109 The results of a recent survey indicate that the average cost of patent litigation where the amount at issue is between \$1 million to \$25 million is \$2 million. See Report of the Economic Survey, Am. Intellectual Prop. Law Ass'n, at 22 (2003).

${ }^{110}$ In one of the relatively few decisions carefully distinguishing between jurisdictional (i.e., constitutional or statutory) and discretionary/policy considerations in the context of patent declaratory judgment claims, the jurisprudential significance of license negotiations was explained as follows:

In many cases . . , it is the threat of litigation which serves as the motivating factor for negotiation. This being the situation, it is more analytically sound to treat the questions of settlement and negotiation as part of the discretion issue. In other words, an explicit threat of patent litigation gives rise to a reasonable apprehension of suit and simultaneously provides the initiative to enter negotiations designed to avoid that litigation. The controversy thus becomes ripe for adjudication as soon as the initial threat of patent litigation is made; but so long as one party reasonably relies on the forbearance of the other during subsequent negotiations, there may be equitable and public policy reasons for discretionary dismissal of a declaratory action when one party unfairly takes advantage of that forbearance to secure a more convenient forum. 
In many cases, allocating factors such as these, which do not negate the existence of a real, immediate controversy, to the discretionary analysis will not change the outcome of the case. In such cases, only the basis on which the court's decision to hear the declaratory judgment claim rests will change. ${ }^{11}$ Nevertheless, it is important, for many reasons, to distinguish between constitutional and statutory bases for denying jurisdiction and those that should be regarded as policy considerations. ${ }^{112}$

\section{The "Infringer Activity" Prong}

The courts also confuse jurisdictional and policy considerations when evaluating the sufficiency of the potential infringer's activity. As noted above, the courts profess to permit patent challengers to proceed with declaratory judgment claims, assuming the requisite reasonable apprehension, even if they are not presently engaging in infringing activity. "Meaningful preparation" to engage in activity that could constitute infringement is said to be enough. ${ }^{114}$ Nevertheless, even where infringers are engaged in significant preparatory activity, the courts have dismissed their declaratory judgment claims on the ground, inter alia, that the potentially infringing products could change before they are finalized and marketed. In so doing, the courts mistake the jurisdictional significance of the potential for product evolution.

For example, in Intermedics, Inc. v. Ventritex Co., ${ }^{115}$ the Federal Circuit held that no actual controversy existed to support a patentee's request for declaratory relief when the product at issue-an implantable defibrillator — had not yet received FDA approval. ${ }^{116}$ According to the court, two factors supported its conclusion: (1) the uncertainty

Agridyne Tech., Inc. v. W.R. Grace \& Co., 863 F. Supp. 1522, 1527 n.6 (D. Utah 1994).

${ }^{111}$ See id. (noting that its proposed reshuffling of the jurisdictional analysis would not change the outcome in that case)

112 See infra notes 118-167 and accompanying text.

${ }^{113}$ See supra notes 15, 17 and accompanying text.

${ }^{114}$ See supra note 17 for a description of the various formulations of the test for infringer activity.

115991 F.2d 808, 1993 WL 87405 (Fed. Cir. Feb. 22, 1993) (unpublished table decision).

${ }^{116}$ See id., at*4; see also Telectronics Pacing Systems, Inc. v. Ventritex, Inc., 982 F.2d 1520, 1527 (Fed. Cir. 1992) (affirming district court decision that it lacked jurisdiction over a patentee's claim for a declaratory judgment of infringement in part because "[t]here was no certainty that the device [at issue] when approved [by the Food and Drug Administration] would be the same device that began clinical trials"). 
regarding when approval might be obtained; and (2) the possibility that the FDA could require changes to the device. ${ }^{117}$ However, even if a court in a particular case is justified in declining to exercise jurisdiction over a declaratory judgment claim in a particular case on the ground that a present expenditure of the court's time and effort is not justified in view of anticipated changes to the product, such a concern is prudential-not jurisdictional-in character. ${ }^{118}$

\section{Prudence vs. Power: It Matters In Patent Cases}

The outcome of many justiciability determinations affecting declaratory judgment claims in patent cases will be the same regardless of whether constitutional or prudential rationales are invoked. ${ }^{119}$ For example, a court's decision that pending license negotiations negate an actual controversy places, to a certain extent, ${ }^{120}$ a declaratory

${ }^{117}$ Teletronics, 982 F.2d at 1527.

118 The Federal Circuit in Intermedics raised the uncertainty regarding the timing of FDA approval and the possibility that changes would occur to the device in the context of its discussion of the jurisdictional requirement of an actual controversy under the Declaratory Judgment Act. See Intermedics, 1993 WL 87405, at*4. And the district court had dismissed the patentee's declaratory judgment claim on the ground that there was no case or controversy between the parties. See Intermedics, Inc. v. Ventritex Co., 775 F. Supp. 1269, 1289-90 (N.D. Cal. 1991). However, the court intermixed the jurisdictional and discretionary aspects of the Declaratory Judgment Act in upholding the district court's judgment of dismissal. See Intermedics, 1993 WL 87405, at *4 ("For these reasons, the district court did not abuse its discretion in determining not to exercise its declaratory judgment jurisdiction for failure to meet the actual controversy requirement of [the Declaratory Judgment Act]."); compare Telectronics Pacing Sys., Inc. v. Ventritex, Inc., 982 F.2d 1520, 1527 (Fed. Cir. 1992) (holding that patentee's declaratory judgment action against accused infringer's pre-FDA approval-stage device could not be maintained on the grounds that (1) the district court lacked jurisdiction to hear it, and (2) dismissal in the exercise of discretion was appropriate).

${ }^{119}$ See, e.g., Agridyne, 863 F. Supp. at 1527 n.6 (distinguishing between constitutional and policy bases for its determination of justiciability, but noting that the case's outcome would be the same under either analysis).

${ }^{120}$ The trial court's rationale for its justiciability determination may affect the ultimate result if the aggrieved party appeals, because it determines the standard of review. A district court's decision on whether jurisdiction exists on particular facts is a question of law, reviewable de novo. BP Chem., 4 F.3d at 978 (citing Shell Oil, 970 F.2d at 888). In contrast, a discretionary declination of jurisdiction is reviewed pursuant to the more deferential "abuse of discretion" standard. See Capo, 387 F.3d at 1354 (citing Wilton v. Seven Falls Co., 515 U.S. 277, 289 (1995)). In either event, the court's findings with respect to the underlying facts are reviewed for clear error pursuant to Federal Rule Of 
judgment claimant in the same position as a decision that the ongoing discussions between the parties serve as an appropriate basis for declining to exercise jurisdiction out of court. Nevertheless, it is important that courts carefully distinguish between the two justiciability rationales in patent cases.

For one thing, the basis for the district court's justiciability decision determines the standard of review on appeal. ${ }^{121}$ Also, the Act on its face precludes the inclusion of prudential factors in the jurisdictional calculus, as the language of Congress made distinct the Act's jurisdictional and discretionary aspects. ${ }^{122}$ Litigants are entitled to have the statute applied as Congress intended.

Furthermore, to the extent that the courts inconsistently assign jurisdictional versus prudential weight to the same or similar facts in declaratory judgment justiciability determinations, outcomes are less predictable. As a result, some potential infringers may be more inclined to initiate litigation rather than acquiesce to royalty demands, while others, unable to justify the cost of potentially extensive motion practice on justiciability on top of the costs and risks of litigating on the merits, may forego business opportunities.

Most importantly, from the standpoint of maintaining a strong national patent system, the courts are more likely to carefully evaluate the policy implications of justiciability determinations when they are attentive to the distinction between the jurisdictional and prudential bases for those decisions. Litigants, in turn, will be motivated to provide courts with more careful analysis. The likely results include the development of better policy and improved judicial decisionmaking.

The Federal Circuit's tendency to decide declaratory judgment justiciability issues on jurisdictional grounds even where the facts more appropriately implicate policy may be attributable to any of several motivations. The court was created to standardize and stabilize national patent law ${ }^{123}$ and to restore confidence in the United States patent

Civil Procedure 52(a). BP Chem., 4 F.3d at 978 (citing Arrowhead, 846 F.2d at 735). Accordingly, a decision dismissing a declaratory judgment claim as a matter of discretion is less subject to reversal on appeal than one made on the same facts but based on the ground that one or both of the jurisdictional prongs has not been met.

${ }^{121}$ See Capo, 387 F.3d at 1354.

${ }^{122}$ See supra notes $81-85$ and accompanying text.

123 See S. REP. No. 97-275, at 4 (1981) ("The creation of the Court of Appeals for the Federal Circuit provides . . . a forum for appeals from throughout the country in areas of the law where Congress determines that there is special need for . . uniformity."); see also Atari, Inc. v. JS \& A Group, Inc., 747 F.2d 1422, 1437 (Fed. Cir. 1984). 
system. ${ }^{124}$ By discouraging decisions on prudential grounds, the Federal Circuit's approach tends to shield patentees against declaratory judgment attack. It also cultivates district court decisions subject to plenary review, giving the Federal Circuit greater jurisprudential control. Furthermore, deciding cases on legal, as opposed to discretionary, grounds is more likely to shield judges from criticisms of judicial activism. Additionally, to the extent justiciability determinations are made and sustained on constitutional grounds, Congress' ability to provide declaratory judgment claimants with greater access to the courts is constrained. ${ }^{125}$

Restricting access to the declaratory judgment remedy in patent cases can be justified on many grounds. For example, readily subjecting patents to declaratory judgment attack would tend to undermine the respect the Federal Circuit was created to engender, for a patent's vitality is in question and potentially impaired any time it is involved in litigation. Furthermore, a restrictive justiciability approach also encourages competitors to allocate resources away from litigation and toward meaningful "designaround" efforts, stimulating innovation that benefits the public as well as the innovator. ${ }^{126}$ It also encourages dispute resolution via negotiation by placing the litigation alternative effectively out of reach until after negotiations have clearly broken down, ${ }^{127}$ and, to that extent, reduces the incidence of litigation, with all the attendant benefits.

${ }^{124}$ See, e.g., Jon F. Merz \& Nicholas M. Pace, Trends in Patent Litigation: The Apparent Influence of Strengthened Patents Attributable to the Court of Appeals for the Federal Circuit, 76 J. PAT. \& TM. OFF. SoC. 579, 579 (1994) (noting the court's progress toward meeting the goal of promoting predictability).

${ }^{125}$ Although Congress cannot affect constitutional jurisdictional limits, it can change or abrogate prudential limitations. See, e.g., United Food \& Comm. Workers Union Local 751 v. Brown Group, Inc., 517 U.S. 544, 551 (1996).

${ }^{126}$ As the Federal Circuit has observed, designing around patents is socially desirable activity:

Designing around patents is ... one of the ways in which the patent system works to the advantage of the public in promoting progress in the useful arts, its constitutional purpose. Inherent in our claim-based system is also the principle that the protected invention is what the claims say it is, and thus that infringement can be avoided by avoiding the language of the claims.

Slimfold Mfg. Co. v. Kinkead Indus., Inc., 932 F.2d 1453, 1457 (Fed. Cir. 1991).

127 See, e.g., Phillips Plastics Corp., 57 F.3d at 1053 (holding that a patentee's statement that declaratory judgment plaintiff's products were "covered by" its patent did not give rise to an actual controversy because the patentee had also offered a license; stating that " $[\mathrm{w}] \mathrm{hen}$ there are proposed or ongoing license negotiations, a litigation controversy 
Similarly, the courts' reluctance to entertain declaratory judgment claims, whether brought by the potential infringer or the patentee, where there is a possibility that the product at issue may change in the future, has some merit. To the extent that a product under development may undergo modifications relevant to the question of infringement before being introduced into the marketplace, there is a risk that resources - those of the court and of the parties - invested in determining patent coverage may be wasted. Additionally, it may be difficult or impossible to determine whether a declaration of infringement or noninfringement is appropriate in circumstances where the product does not yet exist. ${ }^{128}$ In such circumstances, the risk of erroneous infringement determinations is likely higher. ${ }^{129}$

These concerns, however, do not justify refraining from issuing declaratory judgments regarding infringement in every case. Manufacturers frequently modify products even after they are built, introduced, and sold. If the potential for change justified declining to decide infringement, justiciable patent cases would be rare. In addition, patent infringement determinations often must be made without the court's or jury's examination of the actual accused device. For example, where the size or nature of the product precludes its examination in court, surrogates such as drawings, diagrams,

normally does not arise until the negotiations have broken down"); Shell Oil, 970 F.2d at 889 (affirming dismissal of accused infringer's declaratory judgment action where patentee's statements that the accused infringer's activities "“fall within,' are 'covered by,' and are 'operations under"' the patentee's patent were made during license negotiations initiated by the accused, noting that "[i]t is possible that, even after the conversations reached an impasse, [the patentee] might never have sued"); Century Indus., Inc. v. Wenger Corp., 851 F. Supp. 1260, 1264-65 (S.D. Ind. 1994) (dismissing alleged infringer's declaratory judgment claim in part because the parties were "still engaged in discussions aimed at resolving the potential dispute as late as" a week before suit was initiated). Compare Océ-Office Systems, Inc. v. Eastman Kodak Co., 805 F. Supp. 642, 647 (N.D. Ill. 1992) (denying patentee's motion to dismiss accused infringer's declaratory claim where the parties' licensing negotiations "had failed").

${ }^{128}$ See, e.g., Lynn C. Tyler, Injunctions Against Threatened Patent Infringement: Were Lang Pacific Marine and Its Progeny Wrongly Decided?, 4 FED. CIR. B.J. 113, 133-34 (1994) (citing decisions refusing to grant injunctions against threatened infringement on the ground that the product is not yet in existence).

${ }^{129}$ See William M. Landes \& Richard A. Posner, The Economics of Anticipatory Adjudication, 23 J. LEGAL STUD. 683, 690 (1994) (factoring the risk of error attributable to the "information deficit" that may characterize anticipatory adjudication into an economic evaluation of the risks and benefits of, inter alia, declaratory judgment determinations). 
and computer simulations are often employed in the product's stead. ${ }^{130}$ And patent attorneys routinely evaluate infringement and potential infringement based solely on written and oral descriptions, diagrams, or drawings of the product or process at issue. ${ }^{131}$

Furthermore, many declaratory judgment claims seek adjudication of patent validity or enforceability. Such determinations do not require an evaluation of any potentially infringing products.

It is true that a critical step in determining validity or infringement is the step of determining what the claim language means. ${ }^{132}$ Furthermore, patent claims are construed the same way for all purposes, ${ }^{133}$ and the court's decision on claim construction will, as a legal or practical matter, often resolve the question of infringement. ${ }^{134}$ Without a doubt, therefore, attorneys and litigants often prefer to develop their positions on claim construction with the potentially infringing product in mind. And claim construction determinations may, similarly and appropriately, be informed by the court's understanding of the product at issue. Nevertheless, because correct validity determinations can be made without the potentially infringing product, and the cases demonstrate that litigants are sometimes willing to obtain binding validity, enforceability, or even infringement determinations before development or construction of the potentially infringing product or process is complete, the courts should not, as a matter of law, refuse to adjudicate declaratory judgment claims in such circumstances.

${ }^{130}$ See id. at 134 (commenting on the use of manufacturing drawings in infringement determination).

${ }^{131}$ Virtually every legal or equitable issue that can arise in a patent matter turns on the language of the patent claims at issue. As a result, attorneys, judges, and litigants are very accustomed to making patent-related evaluations based on textual and diagrammatic descriptions alone.

${ }^{132}$ See, e.g., SIBIA Neurosciences, Inc. v. Cadus Pharm. Corp., 225 F.3d 1349, 1355 (Fed. Cir. 2000) ("The first step in any invalidity analysis is claim construction ...."); SuperGuide Corp. v. DirecTV Enter., Inc., 358 F.3d 870, 874 (Fed. Cir. 2004) (“A determination of infringement involves a two-step analysis, the first step being to properly construe the asserted claims.").

${ }^{133}$ See, e.g., SmithKline Beecham Corp. v. Apotex Corp., 439 F.3d 1312, 1316 (Fed. Cir. 2006) ("[C]laims must be construed the same way for validity and for infringement ....”).

${ }^{134}$ See, e.g., Netword, LLC v. Centraal Corp., 242 F.3d 1347, 1351 (Fed. Cir. 2001) ("The court's construction of the claims often decides the question of infringement, whether literal infringement or under the doctrine of equivalents.") 
The decision on the plaintiff's motion for reconsideration of the court's refusal to dismiss the defendant's validity declaratory judgment counterclaim in Farmaceutisk Laboratorium Ferring A/S v. Solvay Pharmaceuticals, Inc. ${ }^{135}$ illustrates an appropriate resolution where patent validity is challenged in the pre-infringement stage. The plaintiff-patentee ("FLF") sued the defendant ("Solvay"), asserting that Solvay's manufacture and distribution of a pharmaceutical product to physicians infringed FLF's patent. ${ }^{136}$ Solvay responded with a declaratory judgment counterclaim, requesting that the court declare FLF's patent invalid and not infringed. ${ }^{137}$ Solvay moved for summary judgment on FLF's infringement claims, relying on the experimental use "safe harbor" defense to infringement found in 35 U.S.C. Section 271(e)(1). ${ }^{138}$ FLF then moved to dismiss its infringement claims after learning through discovery that Solvay's activities were not actionable, ${ }^{139}$ and further to dismiss Solvay's counterclaim on the ground that dismissal of the infringement claims dissolved the actual controversy between the parties. $^{140}$

The court found that Solvay continued to possess a reasonable apprehension of suit, because its existing immunity stemmed only from the fact that its product was still undergoing testing required for federal Food and Drug Administration ("FDA") approval, ${ }^{141}$ and because FLF had demonstrated its intent to enforce its patent. ${ }^{142}$ The court further found that Solvay had satisfied the "infringer activity" prong of the jurisdiction test by showing "meaningful preparation" for potentially infringing activity. ${ }^{143}$

${ }^{135} 25$ U.S.P.Q.2d 1344 (N.D. Ga. 1992).

${ }^{136} I d$. at 1346.

${ }^{137} I d$.

${ }^{138} I d$.

${ }^{139} I d$. at 1347.

${ }^{140} I d$.

${ }^{141}$ Id. at 1349. Although FLF had signed a "statement of non-liability as to [Solvay's] past and current activities" and was willing to "stipulate non-liability as to future similar activities," the court held that Solvay's reasonable apprehension persisted because the "future similar activities" covered only future testing activities, which were, in any event, insulated by the Section 271(e)(1) safe harbor. Id. Solvay's clear intent was to market the product commercially upon FDA approval. See id.

${ }^{142} I d$.

${ }^{143} I d$. at 1351. 
Although determining that an actual controversy existed between the parties, the Farmaceutisk Laboratorium court declined to adjudicate Solvay's non-infringement declaratory judgment claim, citing the possibility that the product could change. ${ }^{144}$ However, the court severed the non-infringement issue and permitted Solvay's invalidity claim to proceed. ${ }^{145}$

The court based its decision to sever on several factors. It noted that the "[u]nlike the ... product, the patent is a fixed target," and that "[a] finding of invalidity would settle the issue now, without requiring the wasting of additional resources."146 Apparently anticipating or responding to concerns that the parties might attempt to take inconsistent positions in separate validity and infringement trials, the court observed that "any ruling concerning the patent claims will be binding on the parties in the future[, which] . . . in turn will prevent FLF from winning both issues by arguing contrary interpretations in severed judicial proceedings." 147

The court also discussed the policy considerations underlying its decision:

The practical effect of this ruling is to permit those who seriously wish to practice an art facially preempted by a patent to test the patent's validity before completing the arduous task of obtaining administrative approval without requiring the court to participate in speculation as to the potential infringement of a product whose final formulation has not yet been settled. This position is supported by the purposed and objectives of patent law in general. ${ }^{148}$

The court also recognized the effect a determination of non-justiciability would have on Solvay:

In order to complete the project to the point of being able to mass produce and market its product, Solvay will have committed substantial resources in both time and money

${ }^{144} I d$. at $1351-52$.

${ }^{145} I d$. at 1351.

${ }^{146} I d$.

${ }^{147} I d$.

${ }^{148}$ Id. at 1352. Specifically, the court cited Congress' intent to "protect patent holders' rights, while encouraging improved products to enter the market and while fostering competition to the maximum extent possible." Id. 
.... Solvay . . . simply does not want to assume the financial risk of pending litigation years down the road after having expended significant additional resources on the project. ${ }^{149}$

As noted above, the Farmaceutisk Laboratorium court relied on its discretionary authority under the Declaratory Judgment Act in severing the issues of infringement and validity. ${ }^{150}$ In explaining its decision, it expressly noted the role judicial discretion should play in determining which circumstances justify the adjudication of a declaratory judgment claim. ${ }^{151}$ The court's attentiveness to the distinction between jurisdictional and discretionary considerations in determining justiciability in patent cases, and its recognition of the role discretion should play in distinguishing between the justiciable and the non-justiciable, is commendable.

Farmaceutisk Laboratorium originated as a patentee's infringement action, ${ }^{152}$ and the court spoke specifically of the plight of the drug manufacturer as subject to the uncertainty associated with the FDA approval process. ${ }^{153}$ Different circumstances may well justify a different outcome. Yet the court's approach to evaluating justiciability in patent cases can advantageously be applied in other circumstances. ${ }^{154}$ When, for example, the action is initiated by the potential infringer, the court must determine that it has jurisdictional authority to hear the plaintiff's claim(s), using the "reasonable apprehension/infringer activity" test discussed above before it evaluates whether that jurisdiction ought to be exercised under the particular circumstances of the case. Assuming that the potential infringer has demonstrated its intent to engage in potentially

${ }^{149} I d$. at 1350.

${ }^{150}$ See supra note 143 and accompanying text.

${ }^{151}$ Farmaceutisk Laboratorium, 25 U.S.P.Q.2d at 1353.

${ }^{152}$ See supra note 135 and accompanying text. As the court noted, the patentee's assertion of infringement claims unambiguously signaled its willingness to enforce its patent against the defendant. See Farmaceutisk Laboratorium, 25 U.S.P.Q.2d at 1349. In so doing, the patentee provided the requisite "reasonable apprehension," satisfying, in the first instance, the requirement for an actual controversy. See id.

${ }^{153}$ See supra note 147 and accompanying text.

${ }^{154}$ The decision in Farmaceutisk Laboratorium has received little attention in the courts and commentary. One court has declined to apply the case, stating only that "the Supreme Court and Federal Circuit cases provide sufficient guidance to decide the issues" raised by the parties before it. Infinitech, Inc. v. Vitrophage, Inc., 842 F. Supp. 332, 337 n.3 (N.D. Ill. 1994). 
infringing activity by making "meaningful preparations,"155 and has (and has pled) a good faith basis for challenging the validity and/or enforceability of the patent, the court should not regard the fact that the product or process in question is not complete and on the market as depriving it of jurisdiction to adjudicate at least validity and enforceability. ${ }^{156}$ The court should, of course, evaluate whether, on the circumstances of a particular case, an exercise of its jurisdiction is appropriate.

For example, the fact that the product in question in Farmaceutisk Laboratorium was a pharmaceutical product subject to FDA approval appropriately informed the court's decision to exercise its jurisdiction only to the point of adjudicating validity. ${ }^{157}$ The potential infringer had a good faith basis for challenging the patent's validity. ${ }^{158}$ However, at a time when nearly $40 \%$ of district court patent claim construction decisions are overturned by the Federal Circuit, ${ }^{159}$ it is clear that even the most reasonable, wellfounded basis for a party's position on validity is no guarantee of success in litigation. ${ }^{160}$ Under such circumstances, the court in Farmaceutisk Laboratorium was appropriately concerned that the potential infringer would invest significant effort and expense, above and beyond that which it had already invested, completing FDA-required clinical trials, all the while laboring under the uncertainty that it might be enjoined when it completed the development and approval process. ${ }^{161}$ The court's rationale in this regard applies with equal force to other development ventures requiring significant resources.

New product development always entails investment and risk. But the risks a party assumes in proceeding with product development while aware of a potentially

${ }^{155}$ See supra note 17 and accompanying text.

${ }^{156}$ As noted supra notes 131-148 and accompanying text, in many cases it is possible to correctly determine validity and enforceability, and thus declare the rights and obligations of the parties even as to that issue, even when the product is not complete.

${ }^{157}$ See supra note 147 and accompanying text.

${ }^{158}$ Farmaceutisk Laboratorium, 25 U.S.P.Q.2d at 1353.

${ }^{159}$ See, e.g., Christian Chu, Empirical Analysis of the Federal Circuit's Claim Construction Trend, 16 BERKELEY TECH., L.J. 1075, 1090 (2001) (concluding that nearly $40 \%$ of district court claim construction determinations are overturned by the Federal Circuit). See also Kimberly A. Moore, Are District Court Judges Equipped to Resolve Patent Cases? 15 HARV. J.L. \& TECH. 1, 2 (2001) (citing a 33\% rate).

${ }^{160}$ Whatever the reversal rate or reasons for it, it is clear that a potential infringer who proceeds with development in the face of a presumptively valid patent assumes significant risk, no matter how sound its invalidity or unenforceability position.

${ }^{161}$ See supra notes $147-48$ and accompanying text. 
applicable patent are considerable. U.S. patents are presumptively valid ${ }^{162}$ and a challenger must demonstrate invalidity or unenforceability with clear and convincing evidence to overcome that presumption. ${ }^{163}$ Regardless of the reasonableness of its defenses, it is subject to damages ${ }^{164}$ and injunctive relief upon a finding of infringement. ${ }^{165}$ If a court determines that the infringement defendant did not exercise due care to avoid infringement, the court may award enhanced damages of up to three times the actual damages. ${ }^{166}$ Furthermore, the same determination can lead the court to declare the case "exceptional," and award the patentee its reasonable attorney fees. ${ }^{167}$ These realities should always factor into a court's decision to exercise or decline to exercise declaratory judgment jurisdiction.

Furthermore, the courts have often proclaimed the public policy of preventing owners of invalid patents from exercising monopoly power. ${ }^{168}$ In evaluating the justiciability of declaratory judgment claims in patent cases, the courts should keep in mind that an invalid patent ought to have absolutely no effect-not even the effect of discouraging, in combination with the uncertainties associated with patent litigation, the investment by others in what are, in actuality, public domain activities. To the extent a holder of an invalid patent can discourage such investment, or extract what amounts to ransom in the form of unfounded settlements, such patents are, in fact, given effect.

16235 U.S.C. § 282.

${ }^{163}$ See, e.g., Kao Corp. v. Unilever U.S., Inc., 441 F.3d 963, 968 (Fed. Cir. 2006) ("Because patents are presumed to be valid, see 35 U.S.C. § 282, an alleged infringer seeking to invalidate a patent on obviousness grounds must establish its obviousness by facts supported by clear and convincing evidence."); Agfa Corp. v. Creo Prod. Inc, 451 F.3d 1366, 1377 (Fed. Cir. 2006) ("Unenforceability due to inequitable conduct requires proof of materiality and intent by clear and convincing evidence.").

${ }^{164}$ See 35 U.S.C. § 284 ("Upon finding for the claimant the court shall award the claimant damages adequate to compensate for the infringement, but in no event less than a reasonable royalty for the use made of the invention by the infringer, together with interest and costs as fixed by the court").

${ }^{165}$ See 35 U.S.C. § 283 (2000).

${ }^{166}$ See 35 U.S.C. $\S 284(2000)$.

${ }^{167}$ See 35 U.S.C. $\S 285$ (2000).

${ }^{168}$ See, e.g., SmithKline Beecham Corp. v. Apotex Corp., 403 F.3d 1331, 1354 (Fed. Cir. 2005) ("Both this court and the Supreme Court have recognized that there is a significant public policy interest in removing invalid patents from the public arena.") (citing Cardinal Chem. Co. v. Morton Int'l, Inc., 508 U.S. 83, 100 (1993)). 


\section{CONCLUSION}

The extra-judicial resolution of business disputes doubtlessly ought to be encouraged, and such resolutions must remain available for those who desire them, or are obligated to pursue them by fiduciary duties owed, for example, to corporate shareholders. However, the Declaratory Judgment Act was enacted to provide parties an alternative vehicle for resolving disputes. While courts may appropriately employ the discretion afforded by the Act to encourage business resolutions, patent owners ought not be able to force such resolutions on parties for whose benefit the Act was enacted.

Furthermore, parties engaged in product development are not the only ones who bear the costs even a putatively invalid patent impose. To the extent the developer passes its costs on-costs in the form, for example, of negotiating and paying unwarranted royalties, investing in unnecessary efforts to design around the patent, purchasing insurance to cover infringement risks, potentially squandering resources on developing the product in question to the point the courts will consider sufficient "meaningful preparation" to support a declaratory judgment controversy, and obtaining legal opinions to protect itself from a finding of willful infringement-its customers, shareholders, and business partners pay as well. And to the extent the developer elects not to make these investments, the public at large pays in the form of potentially higher costs to use patented technology, and lack of access to any improved or alternative technologies the developer would have produced had it not elected to forgo its opportunities.

But whether or not applying a more analytically sound approach to determining justiciability results in greater access to the declaratory judgment remedy for putative patent infringers, it will engender more careful analysis by courts and litigants and greater outcome predictability. 